\title{
Feeding strategies and ageing time alter calpain system proteins activities and meat quality of Braford steers
}

\author{
María Sumampa Coria ${ }^{1,2,3}$, Dario Pighin ${ }^{3,4,5}$, Gabriela Grigioni ${ }^{3,4,5, *}$, and Gustavo Adolfo Palma ${ }^{1,2,3, *}$
}

\footnotetext{
* Corresponding Authors:

Gabriela Grigioni

Tel: +54-011-4621-1447

Fax: +54-0385-4509598,

E-mail: grigioni.gabriela@inta.gob.ar

Gustavo Adolfo Palma

Tel: +54-0385-450-9500

Fax: +54-011-4621-2012

E-mail: gustavo.palma@reprobiotec.com

${ }^{1}$ Animal Production and Reproduction

Laboratory, NOA Institute of

Bionanotechnology (INBIONATEC), Villa

El Zanjón, Santiago del Estero, G4206XCP

Argentina

Institute for the Agricultural Development of the Semiarid (INDEAS), Faculty of Agronomy and Agroindustry (FAyA), National University of Santiago del Estero (UNSE), Santiago del Estero, G4200ABT, Argentina

${ }^{3}$ National Council of Scientific and Technical Research (CONICET), Buenos Aires,

C1033AAJ, Argentina

${ }^{4}$ Food Technology Institute - Science and Technology Institute of Sustainable Food Systems, National Institute of Agricultura Technology (INTA), Hurlingham, Buenos Aires, B1712JHB, Argentina

${ }^{5}$ Faculty of Agriculture and Food Sciences, Moron University, Morón, Buenos Aires, B1708JPD, Argentina
}

ORCID

María Sumampa Coria

https://orcid.org/0000-0002-3472-8775 Dario Pighin

https://orcid.org/0000-0003-3846-5797

Gabriela Grigioni

https://orcid.org/0000-0002-9413-0599

Gustavo Adolfo Palma

https://orcid.org/0000-0002-9175-1322

Submitted May 14, 2021; Revised Aug 11, 2021 ; Accepted Sept 11, 2021

\begin{abstract}
Objective: The aim of this study was to evaluate the effect of ageing and feeding strategies on the calpain protease system and meat quality traits in Braford steers.

Methods: Thirty Braford steers were employed; 15 animals were supplemented with corn silage during finishing and 15 were kept only on pasture. Meat quality traits and calpain system protein activity were evaluated in longissimus thoracis et lumborum (LTL) steaks aged for $2,7,14$, and 21 days.

Results: Aged meat showed higher $\mathrm{pH}$ and calcium content, while Warner Bratzler shear force (WBSF) decreased to day 21. No interaction between ageing and diet was seen for quality traits. Steers finished with corn silage showed higher values of water holding capacity, WBSF and free calcium, and lower values of $\mathrm{pH}$ and cooking loss. Calpain and calpastatin activities decreased with ageing. Finishing steers on pasture produced higher values of calpains and lower values of calpastatin activities. The higher values of calpain 1 activity were observed in muscles aged 2 days from pasture finished animals, and the lower activity of the inhibitor in the 21 days aged samples of the same group.

Conclusion: These results suggest a diet by ageing interaction in calpains and calpastatin and this interaction impact in Warner Bratzler Shear Force in Braford LTL muscle.
\end{abstract}

Keywords: Bovine; Calpain System; Calpastatin; Pasture; Supplementation; Tenderness

\section{INTRODUCTION}

In Argentina, beef cattle production systems have been based traditionally on pasture in temperate regions. As a result of the expansion of agriculture, beef cattle production was displaced to tropical and subtropical regions, and British breeds were replaced by other genotypes, such as composites between Bos indicus and Bos taurus breeds [1]. Numerous studies have indicated that steaks from cattle of greater Bos indicus genetic influence were tougher than steaks from Bos taurus cattle [2,3]. Nevertheless, post mortem strategies such as ageing could be effective for improving tenderness [4].

One of the most important proteolytic systems involved in meat tenderization is the calpain system [5]. In skeletal muscle two proteases, calpain 1 and calpain 2, as well as their inhibitor, calpastatin, have been described in detail [6]. Several studies demonstrated that calpain-1 has the most significant role in post mortem proteolysis and meat tenderization $[7,8]$. However, recent studies show that calpain-2 could contribute during extended ageing periods [4]. Giusti et al [9] suggested that lower tenderness of meat is probably not the result of a lower expression of proteases, but is more likely related to an increased calpastatin expression. This was supported by Strydom et al [10], demonstrating an increase in the value of the correlation coefficient between calpastatin activity and Warner Bratzler shear force (WBSF) within ageing time. Therefore, the aim of this study was to determine 
the effect of post mortem ageing $(2,7,14$, and 21 days) on meat tenderness and calpains (1 and 2) and calpastatin activity in beef longissimus thoracis et lumborum (LTL) muscle of Braford steers finished on pasture or with silage supplementation.

\section{MATERIALS AND METHODS}

\section{Animals and sampling}

The present study was conducted with animals from a commercial breeding herd in Santiago del Estero, in northwest Argentina (coordinates $27^{\circ} 17^{\prime} 34.3^{\prime \prime} \mathrm{S}-62^{\circ} 15^{\prime} 14.1^{\prime \prime} \mathrm{W}$ ). Animal handling and experimental procedures were in accordance with the Handbook of Procedures for Animal Welfare of the National Service of Animal Health of Argentina (Servicio Nacional de Sanidad Animal, SENASA). As was described by Coria et al [11], thirty Braford steers were randomly chosen and divided into 2 experimental groups: 15 animals were fed ad libitum pasture and supplemented with corn silage ( $1 \%$ of body weight/animal/day during 120 days) (Suppl) whereas the other 15 steers were fed ad libitum similar pasture without corn supplementation (Contr). Animals on both diets had free access to water. Steers, with $26 \pm 2$ months of age in average, were slaughtered according to standard commercial procedures on the same day after mixing groups to avoid peri-slaughter effects. Carcasses were weighed for hot carcass weight $(\mathrm{HCW})$ determination and were deboned following a 2-day cooling period at $1^{\circ} \mathrm{C}$ to $5^{\circ} \mathrm{C}$. Samples from LTL muscle were vacuum-packed (Dise.SA., thickness $90 \mu \mathrm{m}$, oxygen permeability $50 \mathrm{~cm}^{3} / \mathrm{m}^{2} / 24 \mathrm{~h}, \mathrm{CO}_{2}$ permeability 140 $\mathrm{cm}^{3} / \mathrm{m}^{2} / 24 \mathrm{~h}$, water vapor permeability 6 to $8 \mathrm{~g} / \mathrm{m}^{2} / 24 \mathrm{~h}$ ), and stored at $2^{\circ} \mathrm{C} \pm 1^{\circ} \mathrm{C}$ in darkness for the corresponding ageing time $(2,7,14$, and 21 days); subsequently they were frozen at $-18^{\circ} \mathrm{C}$ until analysis. Before meat quality measurements, samples were thawed at $4^{\circ} \mathrm{C} \pm 1^{\circ} \mathrm{C}$ overnight.

\section{Muscle pH and colour}

Meat colour was assessed using a Commission Internationale d'Eclairage Lab System, which provides values for colour components: $L^{\star}$ (black-white, lightness) and the chromatic coordinates $a^{\star}$ (+ to - , from red to green) and $b^{\star}$ (+ to -, from yellow to blue). Measurements were carried out using a Minolta CR-400 colorimeter (Konica Minolta Sensing, Inc., Bergen, NJ, USA). The instrumental conditions were artificial D65 illuminant, $8 \mathrm{~mm}$ port size and 2-degree standard angle observer. Determinations were carried out on $2.5 \mathrm{~cm}$ thick steaks. Each sample was allowed to bloom for $45 \mathrm{~min}$ at room temperature prior to the first measurement, and six scans of each steak were averaged for statistical analysis. Then, muscle $\mathrm{pH}$ was measured using a Testo $205 \mathrm{pH}$ meter (Testo AG, Lenzkirch, Germany). Each measurement was performed in triplicate, taking the mean values as the assay result.

\section{Water holding capacity and cooking loss}

The water holding capacity (WHC) was determined in duplicate following the filter paper press methodology described by Coria et al [11]. The WHC was expressed as the percentage of meat-free juice expelled (WHC $=$ meat area/total liquid infiltrated area $\times 100$ ). This procedure assumes that the area of the ring of expressed juice absorbed by the filter paper is related to the amount of meat-free water.

The cooking loss (CL) was determined only once by measuring the sample weight before and after heat treatment. Post cooking measurements were done after 20 min cooling at room temperature. Steaks were subjected to heat treatment with dry heat cooking (Ingeniería gastronómica, Buenos Aires, Argentina; grill temperature, $180^{\circ} \mathrm{C}$; temperature of the thermal centre of the samples, $71^{\circ} \mathrm{C}$ ). The $\mathrm{CL}$ was reported as the percentage of weight loss with respect to the initial weight of the sample.

\section{Instrumental tenderness analysis}

Instrumental tenderness was measured using the WarnerBratzler test, assessing the resistance to a shear force in cooked meat. After cooking, samples were cooled down to $4^{\circ} \mathrm{C}$ overnight in refrigerator. Then, cores of $1.3 \mathrm{~cm}$ diameter were obtained parallel to the muscle fiber orientation and sheared once across the middle (perpendicular to the fibers) using a $1.016 \mathrm{~mm}$ Warner Bratzler blade (WB) probe in a TA.XT Plus Texture Analyzer (Stable Micro Systems Ltd, Surrey, UK). The test was performed with a crosshead speed of 2.0 $\mathrm{mm} / \mathrm{s}$ (pre-test), $2.0 \mathrm{~mm} / \mathrm{s}$ (test), $10.0 \mathrm{~mm} / \mathrm{s}$ (post-test). The highest peak in Newton (maximum shear force) was measured in 7 to 10 cores per sample.

\section{Free calcium concentration}

Muscles samples $(12 \mathrm{~g})$ held at $-80^{\circ} \mathrm{C}$ were removed from frozen storage and kept at room temperature for $10 \mathrm{~min}$ before they were finely diced, and then kept on ice again for $20 \mathrm{~min}$ before they were centrifuged at 20,000×g during $20 \mathrm{~min}$ at $4^{\circ} \mathrm{C}$. An aliquot of the supernatant was mixed with $4 \mathrm{M} \mathrm{KCl}$. Finally, calcium concentration was determined in triplicate using the Ca-Color AA kit (Wiener Lab, Rosario, Argentina) following the manufacturer's instructions. Absorbance was read at $570 \mathrm{~nm}$ in a NanoDrop 2000c UV-Vis spectrophotometer (Thermo Scientific, Barrington, IL, USA).

\section{Collagen content}

Meat texture is determined by collagen and is improved with prolonged post mortem ageing [12]. Therefore, total collagen content was determined at the beginning and at the end of ageing storage. Duplicates of each sample $(4 \mathrm{~g})$ were hydrolyzed with sulfuric acid. A solution of hydroxyproline, made 
from a stock solution $(600 \mu \mathrm{g} / \mathrm{mL})$, was used to obtain a standard curve. Samples and standard solution were added to an oxidant solution (chloramine-T) and the formation of a reddish-purple complex with 4-dimethylaminobenzaldehyde was read at $560 \mathrm{~nm}$ using a NanoDrop 2000c UV-Vis Spectrophotometer (Thermo Scientific, USA).

\section{Calpains and calpastatin activity determination}

Activity was measured in frozen samples using the method described by Coria et al [11]. Briefly, from each sample, duplicates of $200 \mathrm{mg}$ of meat were homogenized in $1 \mathrm{~mL}$ of extraction buffer (100 mM Tris- $\mathrm{HCl} ; 10 \mathrm{mM}$ ethylenediaminetetraacetic acid; $0.05 \% \beta$-mercaptoethanol; $\mathrm{pH} 8.3)$ at 13,500 rpm using a D-160 Handheld Homogenizer (Dragon $\mathrm{Lab}$ ) and centrifuged for $30 \mathrm{~min}$ at $4^{\circ} \mathrm{C}$ at $8,800 \times \mathrm{g}$. An aliquot of the supernatant was mixed with glycerol at a final concentration of $30 \%$ and stored at $-80^{\circ} \mathrm{C}$ until calpain activity was analyzed. Concentration of proteins was determined with the Quick Start Bradford protein assay (Bio-Rad, Hercules, CA, USA) following the standard micro plate protocol. For calpastatin activity, another aliquot of supernatant was heat treated in a water bath at $100^{\circ} \mathrm{C}$ for $5 \mathrm{~min}$, centrifuged during $5 \mathrm{~min}$ at $20,000 \pm \mathrm{g}$, and stored at $-80^{\circ} \mathrm{C}$ until analysis.

Calpain and calpastatin activity was determined using the casein zymography. Clear bands indicating calpain activity were quantified comparing the density of each band with the reference standard of each gel. Before statistical analysis, calpain band densities were calculated as a percentage of a standard included in each gel. The standard was a sample of pasture-finished steers taken randomly in the same experiment.

\section{Statistical analysis}

Data were checked for normality using Infostat Software [13]. Meat trait data were analyzed using mixed model methodology. Ageing time, feeding treatment (Suppl or Contr) and their interaction were included as fixed effects and paddock was included as a random effect in the statistical model. For meat traits, HCW was used as covariate. The choice of residual covariance structure was based on the magnitude of the Akaike Information Criterion (lowest is better). If no significant interactions were observed, the data were reanalyzed for main effects only. When a fixed effect was significant, the least significant difference Fisher test was performed to determine differences between individual treatment means. For all assays, the level of significance was set at 0.05 . Linear and quadratic relationships were detected by response curves using orthogonal polynomial contrasts.

\section{RESULTS AND DISCUSSION}

\section{Meat quality}

There was no significant interaction $(\mathrm{p}>0.05)$ between the main effects of all analyzed variables. Therefore, each effect is discussed individually.

Ageing effect: The effect of the different ageing time on meat quality is shown in Table 1. Ageing time produced significant differences in meat $\mathrm{pH}$, showing higher values after 7 days. Nevertheless, the ultimate $\mathrm{pH}$ values observed were within the normal range (5.6 to 5.7) [14]. This effect was described by Stanišić et al [15] and Wyrwisz et al [16]. After slaughter, the $\mathrm{pH}$ decreases due to the accumulation of lactic acid that occurs during anaerobic glycolysis. Then, $\mathrm{pH}$ increases due to the accumulation of post-slaughter (alkaline) protein degradation products, generally caused by the activity of endogenous enzymes, mainly calpains, during ageing [16].

Significant effect of ageing was observed in colour parameters lightness $\left(L^{\star}\right)$ and yellowness $\left(b^{\star}\right)$, even though no differences were observed in redness $\left(a^{*}\right)$. These results are in accordance with a study published by Stanišić et al [15], who showed a significant increase in $L^{\star}$ and $b^{\star}$ during the ageing of longissimus dorsi muscle. Higher values

Table 1. Means and standard deviation of quality attributes evaluated in longissimus thoracis et lumborum muscle during ageing $(2,7,14$, and 21 days)

\begin{tabular}{|c|c|c|c|c|c|c|c|}
\hline \multirow{2}{*}{ Item } & \multicolumn{4}{|c|}{ Ageing } & \multirow{2}{*}{$\mathrm{p}$-value } & \multicolumn{2}{|c|}{ Effect $^{1)}$} \\
\hline & $2 \mathrm{~d}$ & $7 \mathrm{~d}$ & $14 \mathrm{~d}$ & $21 \mathrm{~d}$ & & Linear & Quadratic \\
\hline $\mathrm{pH}$ & $5.60 \pm 0.14^{b}$ & $5.66 \pm 0.10^{a}$ & $5.67 \pm 0.09^{a}$ & $5.67 \pm 0.10^{a}$ & 0.025 & * & NS \\
\hline$a^{\star}$ redness & $16.62 \pm 1.40$ & $16.61 \pm 1.87$ & $17.18 \pm 2.21$ & $17.43 \pm 1.79$ & 0.218 & NS & NS \\
\hline$b^{\star}$ yellowness & $9.14 \pm 1.59^{\mathrm{a}}$ & $8.24 \pm 1.44^{b}$ & $9.09 \pm 1.60^{a}$ & $9.31 \pm 1.42^{a}$ & 0.034 & NS & * \\
\hline WBSF (N) & $68.16 \pm 13.92^{a}$ & $58.76 \pm 14.37^{b}$ & $46.61 \pm 13.52^{c}$ & $39.27 \pm 11.37^{d}$ & $<0.001$ & * & NS \\
\hline Calcium (mM) & $0.64 \pm 0.04^{c}$ & $0.53 \pm 0.15^{b}$ & $0.90 \pm 0.24^{a}$ & $0.93 \pm 0.15^{a}$ & $<0.001$ & * & NS \\
\hline
\end{tabular}

pH, potential of hydrogen; NS, no significant; WBSF, Warner-Bratzler shear force; WHC, water holding capacity; CL, cooking loss.

1) Linear and quadratic response to ageing time.

a-d Values in the same row with different letters differ $(p<0.05)$. 
observed in $L^{\star}$ parameter during ageing could be explained by the protein degradation that occurs during ageing, that leads to the weakening of protein structures, resulting in a greater scattering of light, thus increasing the lightness of meat [17]. Similarly, higher values in $b^{*}$ parameters were described in Brangus steers finished on pasture, in Friesian $\mathrm{x}$ Simmental bulls raised in semi-intensive systems, and in Angus cows and bulls finished on pasture with 14 days of ageing $[16,18,19]$. Wyrwisz et al [16] found $b^{*}$ parameter increased during ageing and explained this difference by changes in the metmyoglobin amount due to meat surface oxidation. Marino et al [20] suggest that ageing could increase the permeability of the sarcolemma to myoglobin with easier accessibility of oxygen leading to a redder meat. Nevertheless, redder meat was not seen in the present study in LTL muscle of Braford steers aged for 21 days.

Warner-Bratzler shear force values decreased linearly with ageing time until day 21 . The percentage changes were in average of $13.8 \%, 31.6 \%$, and $42.4 \%$ after 7,14 , and 21 days, respectively, with respect to the initial value (day 2 post mortem). These results were consistent with previous publications, although the rate of decline varies. Papaleo Mazzucco et al [18] reported a $13.7 \%$ decrease of WBSF after 14 days of ageing in Brangus steers. In Angus heifers and bulls, Tullio et al [19], found a decrease in the WBSF values of $55.9 \%$ in animals finished on grass, and a decrease of $62.5 \%$ in animals finished in feedlot after 14 days of ageing. Wyrwisz et al [16] reported a reduction of $28.9 \%$ in WBSF values in Holstein-Friesian $\times$ Simmental crossbreed bulls muscle aged 21 days. Differences in WBSF values could be explained by different degree of proteolysis in muscle fibers as a result of breeds and nutritional treatment evaluated. Furthermore, improved tenderness during ageing is a result of proteolytic changes that have a major impact on tenderness development. Proteolytic enzymes cause degradation of muscle proteins, leading to changes in muscle fibers, which is correlated with a reduction in the hardness of meat [21].

The WHC and CL values remained constant during ageing time. These characteristics are $\mathrm{pH}$-dependent [21]. Post mortem lactic acid formation reduces the ability of meat to hold water. This phenomena is related to the fact that muscle proteins being in their isoelectric point (for myosin isoelectric point $=5.4$ ) with the weakest ability to bind water [22]. The WHC increases along with the increase in $\mathrm{pH}$ values of meat, due to an increase in the overall negative charge of proteins, which results in repulsion of the filaments, leaving more space for the water molecules [22]. In this study, an increase in $\mathrm{pH}$ during ageing was not enough to produce significant differences in WHC and CL values.

Calcium concentrations were between $0.64 \mathrm{mM}$ and 0.93 $\mathrm{mM}$ and increased linearly during ageing. Likewise, Parrish et al [23] reported that free calcium in beef longissimus muscle at 10 and $14 \mathrm{~d}$ of ageing were 0.64 and $0.97 \mathrm{mM}$, respectively. Furthermore, Senaratne [24] documented that free calcium increased from 0.79 to $0.95 \mathrm{mM}$ from 8 to 28 days of ageing. Consequently, calcium increase during early post mortem ageing could facilitate activation of calpains with subsequent proteolysis of muscle proteins resulting in an improvement on meat tenderness.

In the present study, no differences were observed in between 2 and 21 days of ageing $(3.67 \pm 0.33$ and $2.93 \pm 0.51, \mathrm{p}=$ 0.055). Similarly, in other studies, the total collagen content did not differ in semimembranous and longissimus dorsi muscles of bulls evaluated at 5 and 12 days of ageing $[25,26]$. Total collagen content is mainly responsible for the background toughness of meat post mortem, which is the minimal toughness that can be reached by meat after prolonged storage [27]. As expected, 21 days of ageing were not enough to produce a collagen content decrease in LTL muscle of Braford steers.

Feeding treatment effects: Feeding strategy is the management factor which is most actively used in relation to improvement and/or control of animal performance, nutritional value, eating and technological quality. In agreement with Teira et al [28], corn-finished animals have lower $\mathrm{pH}$ value than the steers that did not receive grain at the end of the finishing period. This could be related to differences in muscle glycogen content, higher in animals fed corn silage [29]. Results of LTL muscle color determination are shown in Table 2. There were no differences in colour parameters between dietary treatments in the present study. Similar, other researchers did not find significant effects of different forage/concentrate ratio diets during finishing on muscle colour [30,31]. Faucitano et al [32] suggest that diet characteristics do not have capital relevance on meat colour,

Table 2. Means and standard error values of meat quality attributes for two feeding treatments measured in thawed longissimus thoracis et lumborum muscle

\begin{tabular}{lccr}
\hline \multirow{2}{*}{ Item } & \multicolumn{2}{c}{ Treatment $^{\mathbf{1})}$} & \multirow{2}{*}{ p-value } \\
\cline { 2 - 3 } & \multicolumn{1}{c}{ Contr } & Suppl & \\
\hline pH & $5.68 \pm 0.11$ & $5.62 \pm 0.10$ & 0.003 \\
Colour lightness $L^{*}$ & $33.61 \pm 2.63$ & $33.11 \pm 2.51$ & 0.287 \\
Colour redness $a^{*}$ & $16.93 \pm 2.02$ & $16.99 \pm 1.69$ & 0.857 \\
Colour yellowness $b^{*}$ & $9.02 \pm 1.65$ & $8.87 \pm 1.46$ & 0.591 \\
WBSF $(\mathrm{N})$ & $48.08 \pm 16.35$ & $58.32 \pm 16.74$ & 0.001 \\
WHC $(\%)$ & $34.57 \pm 5.49$ & $36.62 \pm 4.55$ & 0.052 \\
CL $(\%)$ & $35.55 \pm 2.77$ & $33.12 \pm 2.44$ & $<0.001$ \\
Calcium $(\mathrm{mM})$ & $0.68 \pm 0.20$ & $0.82 \pm 0.26$ & 0.002 \\
Collagen $(\mathrm{mg} / \mathrm{g})$ & $3.28 \pm 0.48$ & $3.31 \pm 0.50$ & 0.803 \\
\hline
\end{tabular}

$\mathrm{pH}$, potential of hydrogen; WBSF, Warner-Bratzler shear force; WHC, water holding capacity; $\mathrm{CL}$, cooking loss.

1) Braford steers finished with: Contr, finished on pasture; Suppl, corn silage supplement at $1 \%$ of body weight per head/day in addition to ad libitum pasture during 120 days. 
probably due to transformation processes that take place in the rumen.

No difference was found in WHC between feeding strategies. Similarly, in other studies, feeding strategy did not produce differences in WHC [32,33]. Nevertheless, the values of CL were significantly different between feeding systems, resulting in meat with lower CL in the supplemented group compared with pasture alone. Many studies have found similar differences in CL between forage- and grain-fed cattle $[34,35]$. Furthermore, differences observed in $\mathrm{pH}$ values between groups and in mechanisms involving post mortem proteolysis like the calpain/calpastatin system can also affect CL values [22]. Explaining the higher CL values obtained in this group [36], pasture-finished steers resulted in higher $\mathrm{pH}$ values and activity of the proteolytic enzymes, and thus produced higher protein fragments, which are more easily lost from the structure during storage and cooking, along with water.

Cooking loos and WHC values were higher than those obtained in other studies performed in Braford steers [30,37]. Nevertheless, in the present study meat was frozen and thawed before being measured, and previously it was reported that cell membrane can be damaged during frozen and thawed process, explaining differences with other studies [38].

As can be seen in Table 2, the calcium content was higher in meat from supplemented steers. Calpains and calpastatin proteins requires the presence of calcium to be activated [21]. In general, less calcium concentration is required for calpastatin to bind to calpains than the calcium concentration required for calpains to reach half-maximal activity, suggesting that if calpains and calpastatin were both presented in sarcoplasm, higher calcium concentrations would result in binding of calpastatin to calpains before it could initiate proteolytic activity [39]. Differences in free calcium concentration were previously associated with vitamin supplementations [40]. Interestingly, the supplementation used in those studies, increased serum calcium in early post mortem creating an influx of calcium into the skeletal muscle causing a decrease in calpain levels, or potentially an increase in calpastatin activity. Likewise, in the present study corn silage supplementation offered could produce the mentioned effect by increasing polyunsaturated fatty acids of sarcoplasmic reticulum membrane, making it more susceptible to oxidation and thereby causing early release of calcium [39]. Although the actual mechanism of oxidation influenced membrane degradation is unclear, Senaratne [24] showed that increased release of calcium during post rigor produce delayed and/or reduced proteolysis in beef, explaining the differences observed in the present study between feeding strategies in calpains and calpastatin activities and in WBSF values.

The WBSF of beef from the corn-supplemented group were higher than for beef from the pasture-only group. The higher $\mathrm{pH}$ values in grass-fed steers compared to grain-fed steers, influences the activity of endogenous enzyme systems at slaughter which, in turn may affect myofibril fragmentation and thus affects ultimate meat tenderness. According to Destefanis et al [41] classification, meat from supplemented animals was hard, while beef from pasture finished animals was acceptably tender. In this sense, Latimori et al [42] showed that meat for Aberdeen Angus, Charolais $\times$ Angus and Holando Argentino steers finished on pasture, with corn silage supplementation $(0 \%, 7 \%$, and $1 \%)$ or with concentrate can be produced without detrimental effect on meat quality, including tenderness. Furthermore, shear force values at one day of aged were similar between steaks from pasture- and concentrate-fed Hereford steers [43]. Additionally corn-finished Braford steers displayed higher WBSF values in 2 day aged meat [11]. Likewise, del Campo et al [30] did not find differences in meat from Hereford and Braford steers finished with high quality pasture compared to meat from animals finished with rangeland plus corn grain. In this sense, del Campo et al [29] suggested that when forage-finished cattle has been compared with concentrate-finished cattle at a common endpoint such as bodyweight, fat thickness over the $\mathrm{LD}$, or degree of marbling, meat quality differences between diets were minimized.

In agreement with another study that has assessed the influence of diet on meat quality and collagen properties, in the present study the collagen content did not differ between the feeding groups [44]. These authors suggest that cattle feed to comparable weights and grades, type of diet had little influence on collagen content [38].

\section{Calpain system}

There was significant interaction between ageing and feeding effect on calpain-1 and calpastatin activity. The higher values of calpain 1 activity were observed in muscles aged 2 days from pasture finished animals, and the lower activity of the inhibitor in the 21 days aged samples of the same group (Table 3).

Most literature indicates that calpain-1 activity is diminished by 14 or 21 days of post mortem ageing in beef [4,7]. In the present study, calpain 1 activity decreased significantly with 21 days of ageing (Table 3). Activity at day 21 remained close to $37 \%$ of its initial activity. Calpain 2 activity decreased with ageing, getting values close to $83 \%$ of its initial activity at 14 days of ageing. Similarly, other authors have described that calpain-2 activity remained close to $80.2 \%$ of its initial activity after 14 days [45]. Additionally, calpastatin activity decreased significantly with 21 days of ageing, getting values close to $67 \%$ of its initial activity (Table 3 ). Previous research differs from those obtained in the present study, because the inhibitor activity could only be determined during the first 
Table 3. Means and standard deviation of activity values of calpains and calpastatin proteins measured in the longissimus thoracis et lumborum muscle of Braford steers

\begin{tabular}{|c|c|c|c|c|c|c|c|c|c|c|}
\hline \multirow{2}{*}{ Protein $^{1)}$} & \multirow{2}{*}{\multicolumn{2}{|c|}{ Feeding strategies ${ }^{2)}$}} & \multicolumn{4}{|c|}{ Ageing time } & \multirow{2}{*}{ SEM } & \multicolumn{3}{|c|}{ Effects $^{3)}$} \\
\hline & & & 2 & 7 & 14 & 21 & & A & $\mathbf{F}$ & $A \times F$ \\
\hline \multirow[t]{2}{*}{ CAPN1 } & Contr & $0.42^{\mathrm{A}}$ & 0.58 & 0.54 & 0.31 & 0.25 & 0.01 & $<0.001$ & $<0.001$ & 0.001 \\
\hline & & & $0.54^{\mathrm{a}}$ & $0.48^{b}$ & $0.24^{c}$ & $0.20^{d}$ & & & & \\
\hline \multirow[t]{2}{*}{ CAPN2 } & Contr & $0.83^{\mathrm{A}}$ & 0.94 & 0.86 & 0.78 & 0.75 & 0.01 & $<0.001$ & $<0.001$ & 0.262 \\
\hline & Suppl & $0.70^{B}$ & 0.81 & 0.71 & 0.66 & 0.62 & & & & \\
\hline & Suppl & $2.06^{\mathrm{B}}$ & 2.33 & 2.07 & 1.97 & 1.87 & & & & \\
\hline & & & $1.78^{\mathrm{a}}$ & $1.52^{\mathrm{ab}}$ & $1.38^{\mathrm{bc}}$ & $1.20^{\mathrm{c}}$ & & & & \\
\hline
\end{tabular}

SEM, standard error of the mean.

1) Protein activity measured by casein zymography (U/g). CAPN1, calpain-1; CAPN2, calpain-2; CAST, calpastatin.

2) Braford steers finished with: Supplementation, corn silage supplement at $1 \%$ of body weight per head/day in addition to ad libitum pasture during 120 days; Contr, finished on pasture.

3) $\mathrm{p}$-value of ageing $(A)$, feeding $(F)$, and $A \times F$ effects.

Feeding strategies significant differences ( $p$-value<0.05) are expressed as different uppercase letters between rows and ageing time significant differences ( $p$-value $<0.05)$ are expressed as different smaller case between columns.

${ }^{A, B}$ Values are significant between feeding strategies $(p<0.05)$.

${ }^{a-d}$ Values within a row with different letters differ $(p<0.05)$.

$48 \mathrm{~h}$ post mortem or until 5 days of ageing [46,47]. Differences observed could be explained by methods used for activity determination. According to Kristensen et al [48], calpastatin activity is often miscalculated as a result of a masking effect when it was assayed by chromatography. If calpastatin binds to inactivated calpain in the assay, the binding sites on calpastatin for active calpain molecules are masked and the calpastatin activity would be underestimated [48].

In our study, finishing steers with corn silage produced lower levels of proteases and higher levels of the inhibitor. In previous research, Volpelli et al. [49] suggested that diets had no effect on calpain and calpastatin activities. However, several authors have described that energy, vitamin supplementation and/or compensatory effect can change calpain system protein activities $[40,50]$. The pre rigor muscle environment is critical in determining the behaviour of myofibrillar proteins and their subsequent impact on meat quality attributes such as tenderness and colour. According to Dransfield [51], the effects of calpains and their inhibitors immediately post mortem, depend on $\mathrm{pH}$ and have an important influence on tenderness. Muscle $\mathrm{pH}$ and temperature also interact continuously during rigor development as they impact on both physical shortening and proteolytic enzyme activity [30]. As previously described, diet can influence the energy status or free calcium content, and this could impact on activities. In the present study, corn silage supplementation produces a decrease in $\mathrm{pH}$ values and an increment in calcium content, and this produces an increase greater of two times in the activity of the inhibitor, generating a tendency of lower calpain activity for every unit of calpastatin. In this sense, the higher calpain activity in 2 days aged beef from pasture finished an- imals probably caused higher proteolysis resulting in tender meat, and the higher activity of the inhibitor in supplemented steers in 2 days aged samples resulted in tougher meat.

Several studies present compelling evidence that the calpain system plays a primary role in post mortem meat tenderness development during ageing [5,6]. Therefore, finishing strategies that produce alterations in muscle calcium content during early post rigor could result in higher calpastatin activity, and may have the potential to influence calpain activity and tenderness during ageing.

\section{CONCLUSION}

Feeding strategies and post mortem ageing in LTL muscle in Braford steers had a significant effect on meat quality, specifically in tenderness. The comprehensive understanding of factors is highly relevant to the development of effective ageing strategies to maximize the positive impacts of ageing. In this sense, the results obtained suggest that ageing produces significant differences up to 21 days. Furthermore, both proteases and their inhibitor activity remained until 21 days of ageing, contributing to the degradation process of muscle fibers and tenderization of meat. A feeding strategy by ageing interaction on calpain system proteins was observed. The higher values of calpain 1 activity were observed in muscles aged 2 days from pasture finished animals, and the lower activity of the inhibitor in the 21 days aged samples of the same group. Likewise, finishing steers on pasture produced lower free calcium concentration and calpastatin activity, and therefore more tender meat than corn silage supplementation. The tougher meat obtained could be due to inactivation of 
calpain by excessive calpastatin activity, stressing its role on meat tenderness.

\section{CONFLICT OF INTEREST}

We certify that there is no conflict of interest with any financial organization regarding the material discussed in the manuscript.

\section{FUNDING}

This work was supported by National University of Santiago del Estero (UNSE) and Faculty of Agronomy and Agroindustry (PI-UNSE 23/A262), National Council of Scientific and Technical Research (PUE 2018 0035), and National Institute of Agricultural Technology (INTA PE26024).

\section{ACKNOWLEDGMENTS}

The authors would like to acknowledge Mrs. Karina Moreno, PhD Sebastian Cunzolo and PhD. Eduardo A. Parellada for the technical assistance in determining the physical characteristics and biochemical composition of beef and to Eng. Horacio Coria and Mgs. Noemi Comba for their technical assistance in handling and shipping samples.

\section{REFERENCES}

1. Rearte D. Meat production in Argentina. Sitio Argentino Prod Animal; c2007 [cited 2021 Feb 26]. pp. 1-25. Available from: https://www.produccion-animal.com.ar

2. Bidner TD, Wyatt WE, Humes PE, Franke DE, Blouin DC. Influence of Brahman-derivative breeds and Angus on carcass traits, physical composition, and palatability. J Anim Sci 2002;80:2126-33. https://doi.org/10.2527/2002.8082126x

3. Pringle TD, Williams SE, Lamb BS, Johnson DD, West RL. Carcass characteristics, the calpain proteinase system, and aged tenderness of Angus and Brahman crossbred steers. J Anim Sci 1997;75:2955-61. https://doi.org/10.2527/1997. $75112955 \mathrm{x}$

4. Colle MJ, Doumit ME. Effect of extended aging on calpain-1 and -2 activity in beef longissimus lumborum and semimembranosus muscles. Meat Sci 2017;131:142-5. https://doi.org/ 10.1016/j.meatsci.2017.05.014

5. Coria MS, Carranza PG, Palma GA. Calpain system in meat tenderization: a molecular approach. Rev MVZ Cordoba 2018;23:6523-36. https://doi.org/10.21897/rmvz.1247

6. Goll DE, Thompson VF, Li H, Wei W, Cong J. The calpain system. Physiol Rev 2003;83:731-801. https://doi.org/10.1152/ physrev.00029.2002

7. Koohmaraie M, Geesink GH. Contribution of postmortem muscle biochemistry to the delivery of consistent meat quality with particular focus on the calpain system. Meat Sci 2006;74:34-43. https://doi.org/10.1016/j.meatsci.2006. 04.025

8. Geesink GH, Kuchay S, Chishti AH, Koohmaraie M. $\mu$-Calpain is essential for postmortem proteolysis of muscle proteins. J Anim Sci 2006;84:2834-40. https://doi.org/10.2527/ jas.2006-122

9. Giusti J, Castan E, Dal Pai M, Arrigoni MDB, Rodrigues Baldin S, De Oliveira HN. Expression of genes related to quality of Longissimus dorsi muscle meat in Nellore (Bos indicus) and Canchim (5/8 Bos taurus $\times 3 / 8$ Bos indicus) cattle. Meat Sci 2013;94:247-52. https://doi.org/10.1016/j. meatsci.2013.02.006

10. Strydom PE, Frylinck L, Montgomery JL, Smith MF. The comparison of three $\beta$-agonists for growth performance, carcass characteristics and meat quality of feedlot cattle. Meat Sci 2009;81:557-64. https://doi.org/10.1016/j.meatsci. 2008.10.011

11. Coria MS, Reineri PS, Pighin D, et al. Feeding strategies alter gene expression of the calpain system and meat quality in the longissimus muscle of Braford steers. Asian-Australas J Anim Sci 2020;33:753-62. https://doi.org/10.5713/ajas.19. 0163

12. Nishimura T. The role of intramuscular connective tissue in meat texture. Anim Sci J 2010;81:21-7. https://doi.org/10. 1111/j.1740-0929.2009.00696.x

13. Di Rienzo JA, Casanoves F, Balzarini MG, Gonzalez L, Tablada M, Robledo CW. InfoStat versión 2012. Córdoba, Argentina: Grupo InfoStat, FCA, Universidad Nacional de Córdoba. Available from: http://www.infostat.com.ar

14. Immonen K, Ruusunen M, Hissa K, Puolanne E. Bovine muscle glycogen concentration in relation to finishing diet, slaughter and ultimate $\mathrm{pH}$. Meat Sci 2000;55:25-31. https:// doi.org/10.1016/S0309-1740(99)00121-7

15. Stanišić N, Petričević M, Živković D, et al. Changes of physicalchemical properties of beef during 14 days of chilling. Biotechnol Anim Husb 2012;28:77-85. https://doi.org/10.2298/ BAH1201077S

16. Wyrwisz J, Moczkowska M, Kurek M, Stelmasiak A, Półtorak A, Wierzbicka A. Influence of 21 days of vacuum-aging on color, bloom development, and WBSF of beef semimembranosus. Meat Sci 2016;122:48-54. https://doi.org/10.1016/ j.meatsci.2016.07.018

17. Beriain MJ, Goñi MV, Indurain G, Sarriés MV, Insausti K. Predicting Longissimus dorsi myoglobin oxidation in aged beef based on early post-mortem colour measurements on the carcass as a colour stability index. Meat Sci 2009;81:43945. https://doi.org/10.1016/j.meatsci.2008.09.009

18. Papaleo Mazzucco JP, Melucci LM, Villarreal EL, et al. Effect of ageing and $\mu$-calpain markers on meat quality from Brangus steers finished on pasture. Meat Sci 2010;86:878-82. https:// doi.org/10.1016/j.meatsci.2010.07.015 
19. Tullio RR, Juárez M, Larsen IL, Basarab JA, Aalhaus JL. Effect of quality parameters on beef meat tenderness. iComstProceedings; 2013. pp. 1-5.

20. Marino R, Albenzio M, della Malva A, Caroprese M, Santillo A, Sevi A. Changes in meat quality traits and sarcoplasmic proteins during aging in three different cattle breeds. Meat Sci 2014;98:178-86. https://doi.org/10.1016/j.meatsci.2014. 05.024

21. Huff Lonergan E, Zhang W, Lonergan SM. Biochemistry of postmortem muscle - lessons on mechanisms of meat tenderization. Meat Sci 2010;86:184-95. https://doi.org/10.1016/j. meatsci.2010.05.004

22. Huff-Lonergan E, Lonergan SM. Mechanisms of water-holding capacity of meat: The role of postmortem biochemical and structural changes. Meat Sci 2005;71:194-204. https://doi. org/10.1016/j.meatsci.2005.04.022

23. Parrish FC, Selvig CJ, Culler RD, Zeece MG. CAF activity, calcium concentration, and the 30,000-Dalton component of tough and tender bovine longissimus muscle. J Food Sci 1981;46:308-11. https://doi.org/10.1111/j.1365-2621.1981. tb14593.x

24. Senaratne LS. Mechanism and control of beef toughening during retail display in high oxygen modified atmosphere packages [Theses and Dissertations]. Lincoln, NE, USA: Animal Science, Univ Nebraska-Lincoln; 2012. https://digitalcommons.unl.edu/animalscidiss/54

25. Silva JA, Patarata L, Martins C. Influence of ultimate $\mathrm{pH}$ on bovine meat tenderness during ageing. Meat Sci 1999;52: 453-9. https://doi.org/10.1016/S0309-1740(99)00029-7

26. Palka $\mathrm{K}$. The influence of post-mortem ageing and roasting on the microstructure, texture and collagen solubility of bovine semitendinosus muscle. Meat Sci 2003;64:191-8. https:// doi.org/0.1016/s0309-1740(02)00179-1

27. Christensen M, Ertbjerg P, Failla S, et al. Relationship between collagen characteristics, lipid content and raw and cooked texture of meat from young bulls of fifteen European breeds. Meat Sci 2011;87:61-5. https://doi.org/10.1016/j.meatsci. 2010.09.003

28. Teira G, Perlo F, Bonato P, et al. Finishing phase and meat quality. 2. Tenderness. Rev Argentina Prod Anim 2004;24 (suppl 1).

29. del Campo M, Brito G, de Lima JMS, et al. Effects of feeding strategies including different proportion of pasture and concentrate, on carcass and meat quality traits in Uruguayan steers. Meat Sci 2008;80:753-60. https://doi.org/10.1016/j. meatsci.2008.03.026

30. del Campo M, Brito G, Soares de Lima J, Hernández P, Montossi F. Finishing diet, temperament and lairage time effects on carcass and meat quality traits in steers. Meat Sci 2010;86:908-14. https://doi.org/10.1016/j.meatsci.2010.07. 014

31. Latimori NJ, Kloster AM, García PT, Carduza FJ, Grigioni
G, Pensel NA. Diet and genotype effects on the quality index of beef produced in the Argentine Pampeana region. Meat Sci 2008;79:463-9. https://doi.org/10.1016/j.meatsci.2007.10. 008

32. Faucitano L, Berthiaume R, D’Amours M, Pellerin D, Ouellet DR. Effects of corn grain particle size and treated soybean meal on carcass and meat quality characteristics of beef steers finished on a corn silage diet. Meat Sci 2011;88:750-4. https://doi.org/10.1016/j.meatsci.2011.03.008

33. He L, Wu H, Wang G, Meng Q, Zhou Z. The effects of including corn silage, corn stalk silage, and corn grain in finishing ration of beef steers on meat quality and oxidative stability. Meat Sci 2018;139:142-8. https://doi.org/10.1016/j.meatsci. 2018.01.023

34. Mandell IB, Buchanan-Smith JG, Campbell CP. Effects of forage vs grain feeding on carcass characteristics, fatty acid composition, and beef quality in Limousin-Cross Steers when time on feed is controlled. J Anim Sci 1998;76:2619-30. https:// doi.org/10.2527/1998.76102619x

35. Vestergaard M, Therkildsen M, Henckel P, Jensen LR, Andersen $\mathrm{HR}$, Sejrsen K. Influence of feeding intensity, grazing and finishing feeding on meat and eating quality of young bulls and the relationship between muscle fibre characteristics, fibre fragmentation and meat tenderness. Meat Sci 2000;54: 187-95. https://doi.org/10.1016/s0309-1740(99)00098-4

36. Purslow PP, Oiseth S, Hughes J, Warnerd RD, Warner RD. The structural basis of cooking loss in beef: Variations with temperature and ageing. Food Res Int 2016;89:739-48. https:// doi.org/10.1016/j.foodres.2016.09.010

37. Orellana C, Peña F, García A, et al. Carcass characteristics, fatty acid composition, and meat quality of Criollo Argentino and Braford steers raised on forage in a semi-tropical region of Argentina. Meat Sci 2009;81:57-64. https://doi.org/10.1016/ j.meatsci.2008.06.015

38. Lagerstedt Å, Enfält L, Johansson L, Lundström K. Effect of freezing on sensory quality, shear force and water loss in beef m. longissimus dorsi. Meat Sci 2008;80:457-61. https:// doi.org/10.1016/j.meatsci.2008.01.009

39. Chao M. Impact of wet distillers grains plus solubles and antioxidants on a basic mechanism of beef tenderization [Theses and Dissertations]. Lincoln NE, USA: Animal Science, University of Nebraska; 2015. http://digitalcommons.unl. edu/animalscidiss/105

40. Korn KT, Lemenager RP, Claeys MC, Waddell JN, Engstrom $\mathrm{M}$, Schoonmaker JP. Supplemental vitamin $\mathrm{D}_{3}$ and zilpaterol hydrochloride. II. Effect on calcium concentration, muscle fiber type, and calpain gene expression of feedlot steers. J Anim Sci 2013;91:3332-40. https://doi.org/10.2527/jas.20125962

41. Destefanis G, Brugiapaglia A, Barge MT, Dal Molin E. Relationship between beef consumer tenderness perception and Warner-Bratzler shear force. Meat Sci 2008;78:153-6. 
https://doi.org/10.1016/j.meatsci.2007.05.031

42. Latimori N, Kloster AM, Amigone MA, García PT, Carduza FJ, Pensel NA. Beef quality according to genotye and feeding system. Rev Argentina Prod Anim 2005; 25(Suppl. 1):365-7.

43. Realini CE, Duckett SK, Brito GW, Dalla Rizza M, De Mattos D. Effect of pasture vs. concentrate feeding with or without antioxidants on carcass characteristics, fatty acid composition, and quality of Uruguayan beef. Meat Sci 2004;66:567-77. https://doi.org/10.1016/S0309-1740(03)00160-8

44. Moran L, O'Sullivan MG, Kerry JP, et al. Effect of a grazing period prior to finishing on a high concentrate diet on meat quality from bulls and steers. Meat Sci 2017;125:76-83. https:// doi.org/10.1016/j.meatsci.2016.11.021

45. Koohmaraie M. Quantification of Ca2(+)-dependent protease activities by hydrophobic and ion-exchange chromatography. J Anim Sci 1990;68:659-65. https://doi.org/10.2527/1990. 683659x

46. Ilian MA, Morton JD, Kent MP, et al. Intermuscular variation in tenderness: Association with the ubiquitous and musclespecific calpains. J Anim Sci 2001;79:122-32. https://doi.org/ $10.2527 / 2001.791122 x$
47. Pomponio L, Ertbjerg P. The effect of temperature on the activity of $\mu$ - and $\mathrm{m}$-calpain and calpastatin during postmortem storage of porcine longissimus muscle. Meat Sci 2012;91:50-5. https://doi.org/10.1016/j.meatsci.2011.12.005

48. Kristensen L, Christensen M, Ertbjerg P. Activities of calpastatin, $\mu$-calpain and $\mathrm{m}$-calpain are stable during frozen storage of meat. Meat Sci 2006;72:116-20. https://doi.org/ 10.1016/j.meatsci.2005.06.010

49. Volpelli LA, Failla S, Sepulcri A, Piasentier E. Calpain system in vitro activity and myofibril fragmentation index in fallow deer (Dama dama): Effects of age and supplementary feeding. Meat Sci 2005;69:579-82. https://doi.org/10.1016/j.meatsci. 2004.09.009

50. Kristensen L, Therkildsen M, Riis B, et al. Dietary-induced changes of muscle growth rate in pigs: Effects on in vivo and postmortem muscle proteolysis and meat quality. J Anim Sci 2002;80:2862-71. https://doi.org/10.2527/2002.80112862x

51. Dransfield E. Optimisation of tenderisation, ageing and tenderness. Meat Sci 1994;36:105-21. https:/doi.org/10.1016/ 0309-1740(94)90037-X 